\title{
Efficacy of Clerodendrum infortunatum on Wound Healing in Streptozotocin-Induced Diabetic Rats
}

\author{
Sidarth S. Panigrahi ${ }^{1}$, Raju Prasad ${ }^{*}$, Mahendra Ram ${ }^{1}$, Dipshikha $^{1}$, \\ A.K. Sharma ${ }^{2}$, B.K. Roy ${ }^{1}$ and K.K. Singh $^{3}$ \\ ${ }^{1}$ Department of Veterinary Pharmacology and Toxicology, College of Veterinary Science and \\ Animal Husbandry, BAU, Kanke, Ranchi-834 006, Jharkhand, India \\ ${ }^{2}$ Department of Veterinary Surgery and Radiology, College of Veterinary Science and Animal \\ Husbandry, BAU, Kanke, Ranchi-834 006, Jharkhand, India \\ ${ }^{3}$ Department of Pathology, College of Veterinary Science and Animal Husbandry, BAU, \\ Kanke, Ranchi-834 006, Jharkhand, India \\ *Corresponding author
}

\section{A B S T R A C T}

\begin{tabular}{|c|}
\hline Keywords \\
\hline $\begin{array}{l}\text { C. infortunatum, } \\
\text { Ointment, } \\
\text { Oxidative stress, } \\
\text { Wound healing, } \\
\text { Rat }\end{array}$ \\
\hline Article Info \\
\hline $\begin{array}{l}\text { Accepted: } \\
\text { 17 January } 2018 \\
\text { Available Online: } \\
\text { 10 February } 2018\end{array}$ \\
\hline
\end{tabular}

The Clerodendrum infortunatiom Linn (CI) is one of the most important medicinal plant containing different properties like anti-inflammatory activities, anti-microbial activities, wound healing, promotes neo-vascularisation, and reduces oxidative stress. The present study was undertaken to evaluate the wound healing activity of hydro-alcoholic (70\% ethanol) leaves extract of $C$. infortunatum Linn as $4 \%$ ointment in cutaneous wound model in diabetic rats. Open excision wounds of $2 \times 2 \mathrm{~cm}^{2}$ were experimentally created on the interscapular region of dorsal aspect of the streptozotocin-induced diabetic rats to evaluate the time dependent (days 3, 7 and 15) wound healing effects of C. infortunatum ointment (4\%). Thirty six acclimatized healthy Wistar rats $(120-150 \mathrm{~g})$ were procured from LARS, IVRI, Izatnagar (U.P.), India divided into two groups namely control and treated consisting of 18 rats each and further divided into three sub group $(n=6)$. The ointment base (90\% soft paraffin, 5\% hard paraffin, 5\% lanolin) and 4\% ointment in ethanolic extract of CI was applied twice daily on wound area in control and treated rats respectively. The \% wound contraction, oxidative stress related parameter (SOD, CAT, GSH and LPO), hydroxyproline content and histopathology were estimated. The significantly higher $(\mathrm{p}<0.001) \%$ wound contraction was found in treated group on day 7 and 15 as compared to control. The levels of SOD, Catalase and GSH in the diabetic treated group were significantly increased and level of MDA was significantly reduced on days 3, 7 and 15 as compared to control group. H \& E stained tissue sections of treated wound showed marked proliferation of fibroblasts, more collagen deposition, well-formed capillaries, more granulation tissue covered with newly formed epithelial layer as compared to control sections. In conclusion, treatment of C. infortunatum ointment (4\%) showed faster and organized healing of cutaneous wounds in streptozotocin-induced diabetic rats. 


\section{Introduction}

A wound is described as loss in continuity of skin or tissue due to violence or trauma (Strodtbeck, 2001). Wound healing is an innate mechanism of action that works reliably most of the time. Normal wound healing involves four temporally overlapping phases i.e. hemostasis, inflammation, proliferation and maturation (Diegelmann and Evans, 2004). There are two types of therapy, firstly the phytotherapy and secondly the chemotherapy (Davis et al., 1994). Due to unwanted effects of chemotherapy, shifting to phytotherapy is imperative. The WHO has been promoting traditional medicine as it is less expensive, comprehensive medical, especially in developing countries (Shafiuddin et al., 2009). The plant, Clerodendrom infortunatum belongs to the family "Verbenaceae" and commonly known as "Bhant" grows throughout the country and used for medicinal purpose (Dymock, 1976). It is an East Indian shrub, the leaves and roots reported to be effective externally to cure tumours and certain skin diseases. It acts as a tonic when employed internally (Maisch, 1885). The leaves are bitter acrid, thermogenic, laxative, cholagogue, antiseptic, demulcent, anti-inflammatory, vermifuge, expectorant, antipyretic and tonic and are useful in vitiated conditions of kapha, helminthiasis, ascarides, abscesses, tumours, leprosy, skin diseases, indolent ulcers, cough, bronchitis, inflammations, intermittent fevers, malarial fever, general debility and proctoptosis (Tyler and Robbers, 1999). Some preliminary works on the wound healing property of $C$. infortunatum leaf extract have carried out in the recent past (Pandarinathan et al., 1998; Mehmood et al., 2011). Diabetes and its subsequent complications present a significant challenge to our healthcare system. The common complications associated with the delayed wound healing in the diabetes are decrease in production of growth factors, diminished angiogenic response, alteration in macrophage function, less quantity of granulation tissue, less collagen accumulation, decrease in migration and proliferation of keratinocyte and fibroblasts (Gibran et al., 2002; Galiano et al., 2004; Falanga, 2005; Galkowska et al., 2006; Goren et al., 2006; Maruyama et al., 2007) There were no available reports regarding the wound healing effect of hydro-alcoholic leave extracts of $C$. infortunatum.

In view of above facts, the present study was designed to investigate the time-dependent effect of $4 \%$ ointment of hydro-alcoholic leaves extract of $C$. infortunatum in excisional wound model in diabetic rats.

\section{Materials and Methods}

\section{Animals used}

The adult Wistar rats (140-200g) were procured from Laboratory Animal Resource Section, IVRI, Izatnagar (U.P.), India. The animals were housed in polypropylene cages and provided fresh water and feed ad libitum in departmental animal house at a temperature of $22 \pm 2{ }^{\circ} \mathrm{C}$. All the animals were acclimatized for a period of 15 days prior to the commencement of the experiments. The experimental protocols involved in this study were approved by the Institutional Animal Ethics Committee (No.528/RVC/IAEC/140).

\section{Extract of $C$. infortunatum leaves and ointment preparation}

$250 \mathrm{gm}$ shade dried powdered leaves of $C$. infortunatum was weighed and immersed in a hydro-alcoholic solution (30\% distilled water $+70 \%$ ethanol) in a flask stoppered and was kept at room temperature for 48 hours and was stirred at 3-4 interval at $150 \mathrm{rpm}$ in an orbital shaker. 
The contents were filtered through the muslin cloth. Then it was filtered through Whatman No.1 filter paper. The extract was filtered, concentrated in vacuum followed by moist drying in hot water bath at $40-50^{\circ} \mathrm{C}$. After scratching, dried powder of the extract was obtained. The extractive value of ethanolic extract was 17.67 percent.

$4 \%$ ointment of ethanolic extract was prepared in ointment base containing 90\% paraffin, 5\% lanolin and 5\% hard paraffin on ointment slab.

\section{Diabetic model}

Streptozotocin (Hi-media limited) powder was used to developed diabetic model in rats. Rats were starved for overnight and their fasting blood glucose level was determined using glucometer (On Call Plus, ABCL 398 Tianmushan Rd. Hanzhou, China) which needed just $1 \mu \mathrm{L}$ of blood usually obtained from tail vein. Streptozotocin solution freshly prepared in citrate buffer with $\mathrm{pH} 7.4$ was then administered to each rats @ $50 \mathrm{mg} / \mathrm{kg}$ body weight through intraperitonial injection. After 48 hours of administration of streptozotocin injection, rats were again monitored for blood glucose and the animals, which showed approximately 3 times fasting blood glucose level, were selected for further protocol of the experiments. These diabetic rats were kept under observation for seven more days then wound was created as described below.

\section{Wound model}

The diabetic rats were anesthetised with an intraperitoneal (i.p.) injection of xylazine (10 $\mathrm{mg} / \mathrm{kg}$ b.w.) and ketamine (50 mg/kg b.w.) and shaved on the inter-scapular region of dorsal aspect. Approximately 2 × $2 \mathrm{~cm}^{2}$ (400 $\mathrm{mm}^{2}$ ) open excision-type wound was created on the back of the diabetic rats to the depth of loose subcutaneous tissue and were housed individually in properly disinfected polypropylene cages.

\section{Ointment application}

Thirty six diabetic rats were taken and divided into two groups consisting of 18 rats each and each group was further subdivided into 3 subgroups (i.e., days 3, 7 and 15) with 6 animals in each sub group. $(n=6)$.

1. Group I (control): The ointment base (90\% soft paraffin, 5\% hard paraffin, 5\% lanolin) was topically applied on wound twice daily.

2. Group II (treated): The $4 \%$ C. infortunatum ointment was topically applied on wound twice daily.

\section{Measurement of wound area}

Wound area was measured on days $0,3,7$ and 15 post-wounding by tracing its contour using a transparent paper. The area $\left(\mathrm{mm}^{2}\right)$ within the boundaries of each tracing was determined planimetrically and expressed as percent wound contraction and calculated by the Wilson's formula:

Per cent wound contraction $=$

0-day wound area-unhealed wound area

0-day wound area

\section{Photographic evaluation}

Wounds were photograph from the same distance above wound on days 0, 3, 7 and 15 post-wounding by digital camera (Sonycyber-shot 16.1 mega pixels).

\section{Tissue harvesting and processing}

Rats from each group were sacrificed by overdose of diethyl ether on days 3, 7 and 15 to collect granulation tissue. The tissue was 
immediately divided into two parts. One portion was kept for estimation of oxidative stress related parameters and hydroxyproline content (this portion were stored at $-40^{\circ} \mathrm{c}$ till processing). The second portion was immediately preserved in $10 \%$ neutral buffered formalin for histopathological study.

\section{Preparation of tissue homogenate}

Frozen tissue samples were partially thawed and $1 \mathrm{~g}$ of tissue sample was weighed and 10 $\%$ homogenate was prepared in ice-cold PBS with Remi homogenizer. The homogenate was centrifuged at $3000 \mathrm{rpm}$ for $10 \mathrm{~min}$ in cooling centrifuge. The supernatant of homogenate was used for this experiment.

\section{Estimation of oxidative stress related parameters}

The oxidative stress parameters were estimated in tissue homogenate as per standard protocols. The anti-oxidant enzyme Superoxide dismutase (SOD), Catalase (CAT), and reduced glutathione (GSH) was estimated in tissue homogenate as per the method described by Madesh and Balasubramanian (1998), Bergmeyer (1983) and Prins and Loos (1969) respectively. Lipid peroxidation was estimated in terms of malondialdehyde (MDA) production by the modified method of Stock and Dormandy (1971) as described by Jain (1988).

\section{Estimation of hydroxyproline}

Hydroxyproline was estimated as per the method described by Woessner (1961). About $50 \mathrm{mg}$ from each stored sample was subjected to acid hydrolysis by adding $1 \mathrm{ml} 6 \mathrm{~N} \mathrm{HCl}$ to it in a test tube which was tightly sealed and autoclaved at 50 pound pressure for $3 \mathrm{~h} .2 \mathrm{ml}$ of neutralized sample or standard hydroxyproline solution was taken in $10 \mathrm{ml}$ tube. $1 \mathrm{ml}$ of chloramine $\mathrm{T}$ solution was added to each tube, shaken vigorously and kept at room temperature for $20 \mathrm{~min} .1 \mathrm{ml}$ of perchloric acid solution was added to each tube, mixed well and kept for $5 \mathrm{~min}$ at room temperature. To each tube, $1 \mathrm{ml}$ of $\mathrm{p}$ dimethylaminobenzaldehyde solution was added. The contents of the tubes were thoroughly mixed and incubated in a water bath at $60^{\circ} \mathrm{C}$ for $20 \mathrm{~min}$. Then tubes were cooled at room temperature with a running tap water and read at $557 \mathrm{~nm}$ with the help of UV/VIS spectrometer, ECIL, India and the data is expressed as $\mathrm{mg} / \mathrm{gm}$ tissue.

\section{Haematoxylin and eosin staining}

The fixed granulation tissue was embedded in paraffin and subjected to sectioning using microtome and $5 \mu \mathrm{m}$ thick tissue sections were placed on slide. Then they were stained with hematoxylin and eosin using standard protocol to see the gross morphological changes in the different stages of wound under light microscope (Olympus BX50, Tokyo, Japan) (10x)

\section{Statistical analysis}

Results are expressed as mean \pm SEM. The data was analyzed by applying two-way ANOVA with Bonferroni's multiple comparison test using the GraphPad Prism v4.03 software (San Diego, CA, USA) and the differences between the control and treated groups were considered statistically significant at $* \mathrm{P}<0.05$.

\section{Results and Discussion}

Effects of $C$. infortunatum ointment (4\%) on $\%$ wound contraction on day 3,7 , and 15 post-wounding in diabetic rats

As evident from the figure 1 , the $\%$ wound contraction in treated rats was significantly higher $(\mathrm{p}<0.01)$ on day $7 \quad(50.53 \pm 2.08$ vs. 
40.12 \pm 2.24$)$ and day $15 \quad(\mathrm{P}<0.001)$ $(87.27 \pm 1.91$ vs. $75.79 \pm 2.92)$ on as compared to control rats respectively. However \% wound contraction was not significantly vary on day 3 (6.52 \pm 0.34 vs. $1.78 \pm 0.22)$. The representative pictures of different stages of wound healing is depicted in figure 2 .

Effects of $C$. infortunatum ointment (4\%) on SOD enzyme on day 3,7 and 15 in diabetic rats

Figure 3 revealed a significant $(\mathrm{p}<0.001)$ increased SOD level in diabetic wounds on day $7(239.61 \pm 9.92)$ vs. $(208.26 \pm 7.77 \mathrm{U} / \mathrm{mg}$ protein) and day $15(264.40 \pm 13.57 \mathrm{U} / \mathrm{mg}$ protein) vs. $(232.77 \pm 10.67 \mathrm{U} / \mathrm{mg}$ protein) in diabetic treated vs. control respectively. However, on day 3, the level of SOD was increased in treated group but not significantly vary as compared to control group (129.01 $\pm 2.59 \mathrm{U} / \mathrm{mg}$ protein) vs. (137.36 $\pm 5.09 \mathrm{U} / \mathrm{mg}$ protein) respectively.

Effects of $C$. infortunatum ointment (4\%) on catalase enzyme on days 3,7 and 15 in diabetic rats

The levels of catalase (Fig. 4) in diabetic treated group was significantly $(\mathrm{p}<0.001)$ increased on day $3 \quad(196.69 \pm 8.85$ $\mathrm{nmol} / \mathrm{min} / \mathrm{mg}$ protein) vs. (113.28 \pm 4.14 $\mathrm{nmol} / \mathrm{min} / \mathrm{mg}$ protein), day 7 (235.95 \pm 9.45 $\mathrm{nmol} / \mathrm{min} / \mathrm{mg}$ protein) vs. (166.53 \pm 6.06 $\mathrm{nmol} / \mathrm{min} / \mathrm{mg}$ protein) and day 15 (271.45 $\pm 9.03 \mathrm{nmol} / \mathrm{min} / \mathrm{mg}$ protein) vs. (211.46 $\pm 7.59 \mathrm{nmol} / \mathrm{min} / \mathrm{mg}$ protein) as compared to diabetic control respectively.

Effects of $C$. infortunatum ointment (4\%) on level of GSH on days 3, 7 and 15 in diabetic rats

Figure 5 depicts the GSH contents and it was found to be significantly $(\mathrm{p}<0.001)$ increased in treated group on day $3 \quad(17.50 \pm 0.37$ $\mathrm{nmol} / \mathrm{mg}$ protein) vs. $(4.54 \pm 0.14 \mathrm{nmol} / \mathrm{mg}$ protein ), day $7(14.36 \pm 0.31 \mathrm{nmol} / \mathrm{mg}$ protein) vs. (7.09 $\pm 0.22 \mathrm{nmol} / \mathrm{mg}$ protein ) and day 15 $(17.50 \pm 0.37 \mathrm{nmol} / \mathrm{mg}$ protein) vs. $(4.54 \pm 0.14$ $\mathrm{nmol} / \mathrm{mg}$ protein ) as compared to control group respectively.

Effects of $C$. infortunatum ointment (4\%) on activities on Lipid peroxidation (MDA level) on days 3, 7 and 15 in diabetic rats

Figure 6 revealed that $C$. infortunatum ointment $(4 \%)$ caused significant $(\mathrm{p}<0.001)$ reduction in MDA level in treated rats on day $3(1.23 \pm 0.03 \mathrm{nmol} / \mathrm{mg}$ protein) vs. (1.67 $\pm 0.09 \mathrm{nmol} / \mathrm{mg}$ protein), day $7(1.07 \pm 0.04$ $\mathrm{nmol} / \mathrm{mg}$ protein) vs. $(2.03 \pm 0.01 \mathrm{nmol} / \mathrm{mg}$ protein) and day $15(0.75 \pm 0.02 \mathrm{nmol} / \mathrm{mg}$ protein) vs. (2.25 $\pm 0.12 \mathrm{nmol} / \mathrm{mg}$ protein) as compared to control rats respectively.

Effects of topical application of $C$. infortunatum ointment $(4 \%)$ on content of hydroxyproline in granulation tissue on days 3,7 , and 15 post wounding in diabetic rats

Figure 7 depicted the significantly $(\mathrm{p}<0.001)$ increased levels of hydroxylproline in treated rats on day $3(2.88 \pm 0.23 \mathrm{mg} / \mathrm{g}$ tissue) vs. $(1.13 \pm 0.14 \mathrm{mg} / \mathrm{g}$ tissue $)$, day $7(6.48 \pm 0.15$ $\mathrm{mg} / \mathrm{g}$ tissue) vs. $(4.16 \pm 0.21 \mathrm{mg} / \mathrm{g}$ tissue) and day $15 \quad(11.45 \pm 0.28 \quad \mathrm{mg} / \mathrm{g}$ tissue $)$ vs. $(9.84 \pm 0.31 \mathrm{mg} / \mathrm{g}$ tissue) as compared to control rats respectively.

Effects of $C$. infortunatum ointment (4\%) on gross pathological changes following $\mathrm{H} \& \mathrm{E}$ staining in diabetic rats

The representative images of $\mathrm{H} \& \mathrm{E}$-stained wound sections are presented in Figure 8. On day $3, C$. infortunatum diabetic treated sections showed more fibroblast with some collagen deposition and few inflammatory cells in comparison to control group. On day 
7, diabetic treated group exhibited uniform and thick granulation tissue formation with marked proliferation of fibroblasts, wellformed new blood vessels and few inflammatory cells. However, wound area of control group was dominated by more cells that are inflammatory and loosely formed less granulation tissue. On day 15 , the thick granulation tissue was dominated by fibroblasts and increased collagen fibers deposition and the complete newly regenerated epithelial layer in diabetic treated rats covered it. However, control groups still showed the dominant presence of inflammatory cells and thin granulation tissue. The $C$. infortunatum ointment treated group showed thick compact extracellular matrix (ECM) covered by epithelial layer resembling normal skin. The fibroblasts proportion also decreased in the treated wounds on day 15 , as compared to diabetic control group on day 15 where as diabetic control rats were still dominated by inflammatory cells with some fibroblasts and collagen deposition.

Fig.1 Showing the effect of C. infortunatum ointment (4\%) on wound contraction (\% contraction) on day 3,7 , and 15 post-wounding in diabetic rats. $(* * \mathrm{P}<0.01$, $* * * \quad \mathrm{P}<0.001$, statistically significant, $\mathrm{NS}=$ non significant, $\mathrm{n}=6$ )

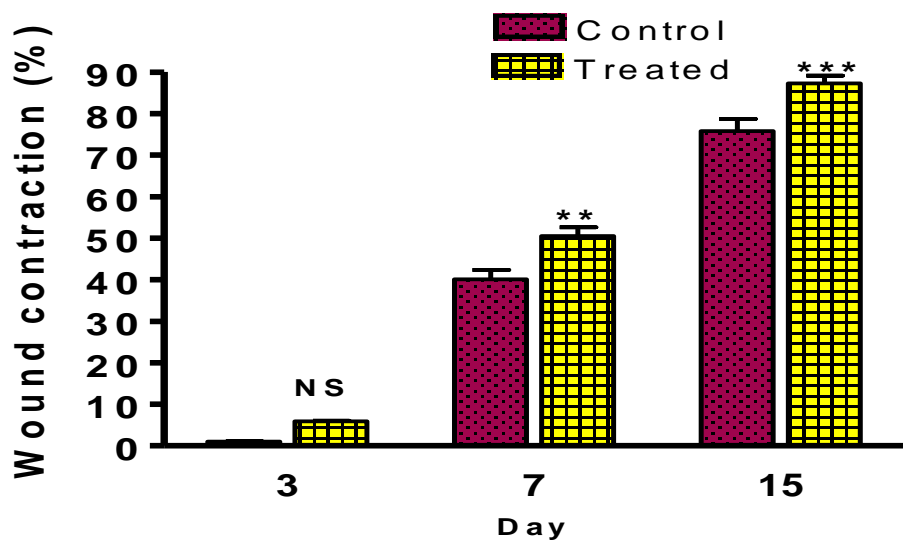

Fig.2 Representative pictures of wound on day 0, 3, 7 and 15 of control and C. infortunatum (4\%) treated diabetic rats

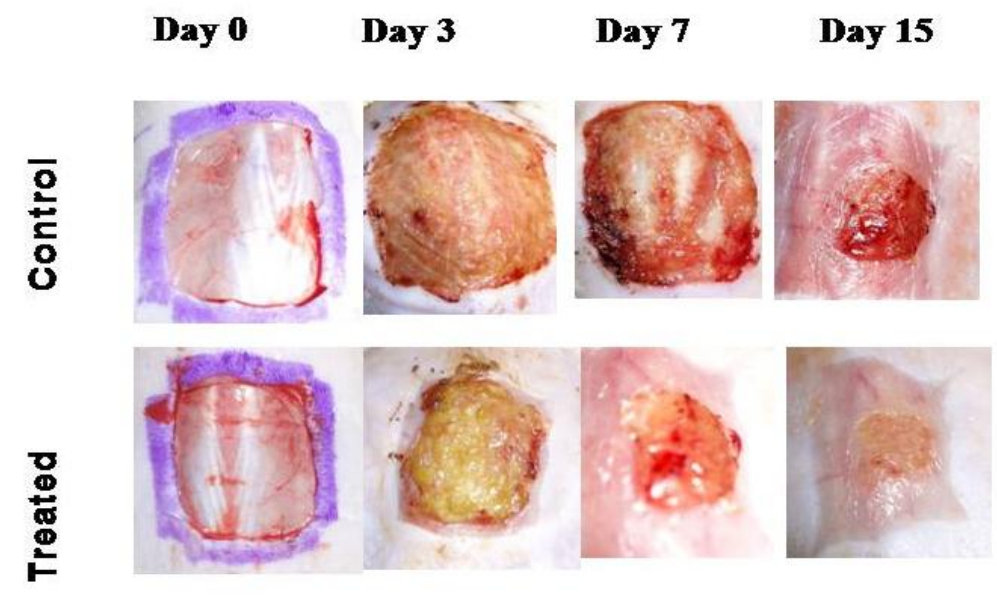


Fig.3 Effect of topical application of C.infortunatum ointment 4\% on activities of SOD on days 3,7 and 15 tissue in diabetic rats. $(* * * \mathrm{P}<0.1$, statistically significant, $\quad \mathrm{NS}=$ non significant, $n=6$ )

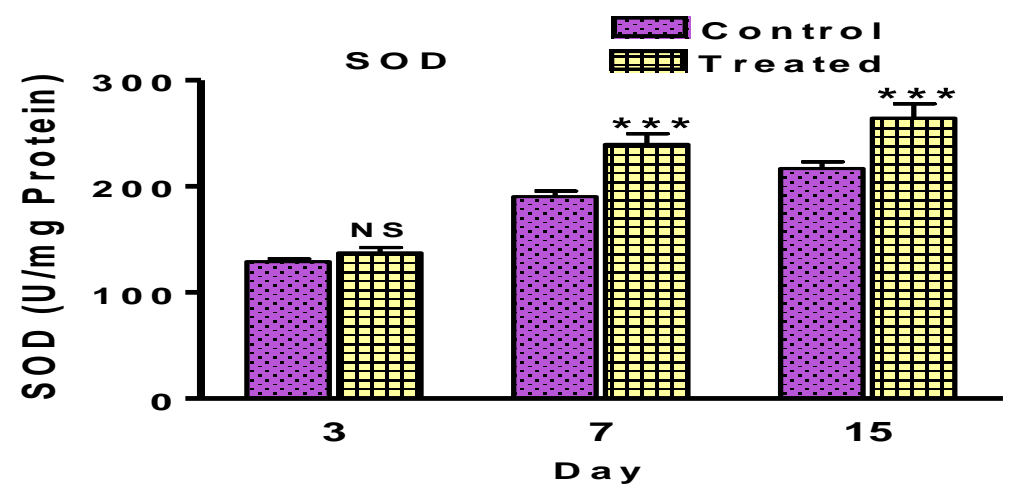

Fig.4 Effect of topical application of $C$. infortunatum ointment (4\%) on activities of catalase on days 3,7 and 15 in diabetic rats. ( $* * * \mathrm{P}<0.001$, statistically significant, $\mathrm{n}=6)$

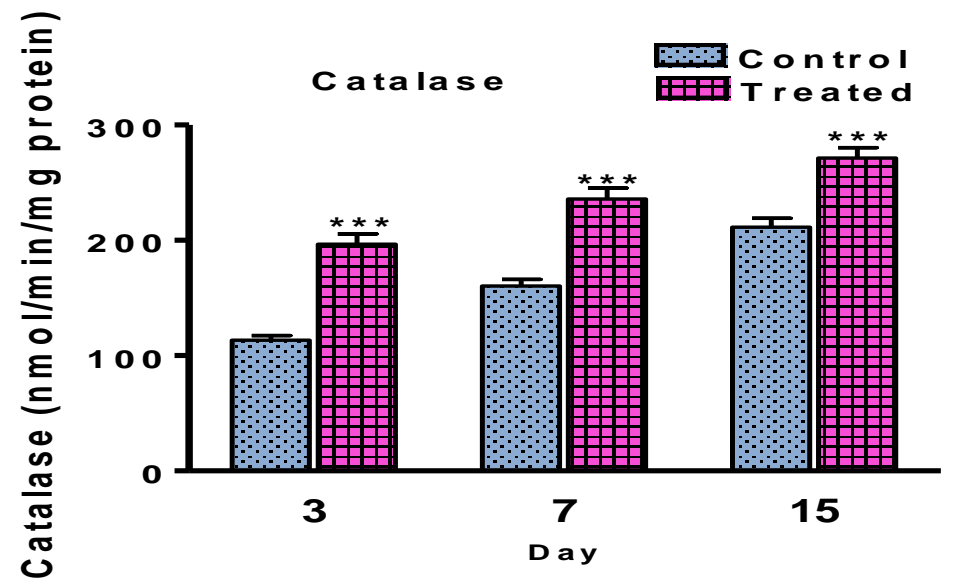

Fig.5 Effect of topical application of $C$. infortunatum ointment $4 \%$ on activities of GSH on days 3,7 and in diabetic rats. (***P $<0.001$, statistically significant, $\mathrm{n}=6$ )

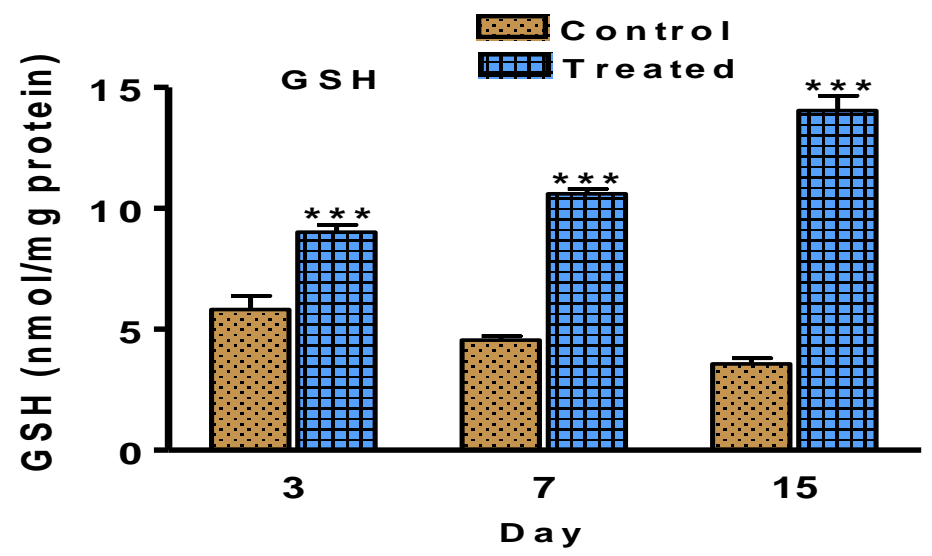


Fig.6 Effect of topical application of $C$. infortunatum ointment (4\%) of MDA levels on days 3, 7 and 15 in diabetic rats. (*** $\mathrm{P}<0.001$, statistically significant, $\mathrm{n}=6)$

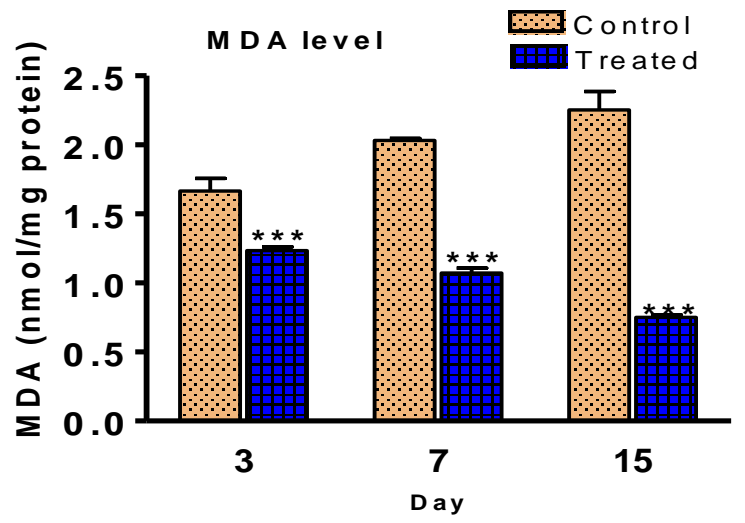

Fig.7 Effect of topical application of $C$. infortunatum ointment (4\%) on activities of hydroxyproline content on days 3,7 and 15 in diabetic rats. $(* * * \mathrm{P}<0.001$, statistically significant, $\mathrm{n}=6$ )

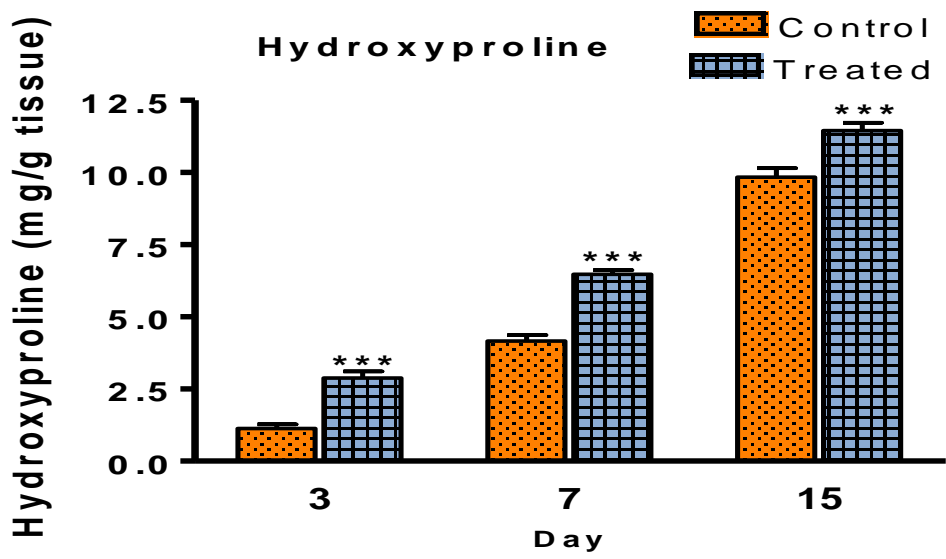

Fig.8 Representative photographs showing (a)increased number of neutrophills in the wound gap (b) higher sprouting of blood vessels and (c) increased the process of neo-vascularisation in the diabetic treated group as compared to control group on day 3,7 and 15 respectively (10x)

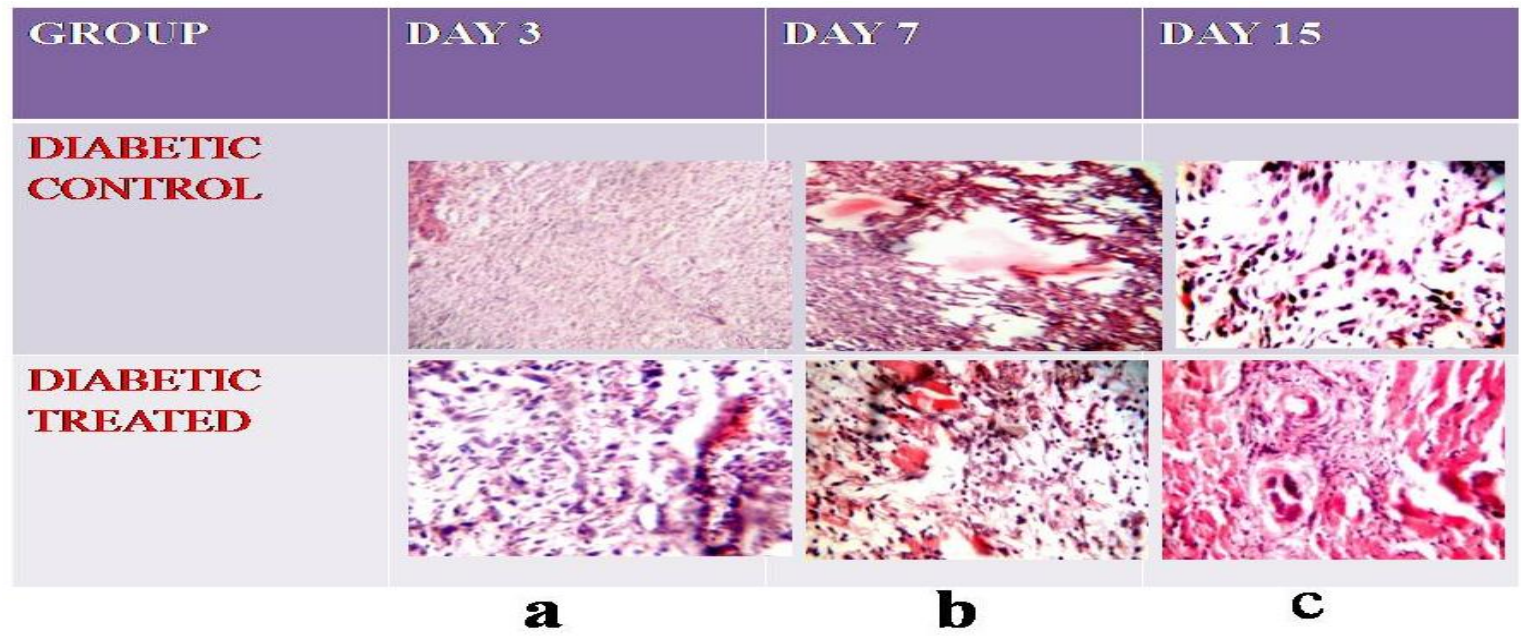


The purpose of this study was to test the hypothesis that the hydro-alcoholic extract of C. infortunatum ointment (4\%) may significantly accelerate the cutaneous wound healing in excision wound model of diabetic rats. Wound healing occurs as a cellular response to injury and involves activation of keratinocytes, fibroblasts, endothelial cells, macrophages, and platelets. Many growth factors and cytokines released by these cell types are needed to coordinate and maintain healing. Many known physiologic factors are responsible for the difficulties in wound healing with diabetes individual. These factors are decreased or impaired growth factor production (Galkowska et al., 2006; Goren et al., 2006; Falanga, 2005), decrease angiogenic response (Galiano et al., 2004), macrophage function (Maruyama et al., 2007), collagen accumulation, epidermal barrier function, quantity of granulation tissue (Falanga, 2005), keratinocyte and fibroblast migration and proliferation, number of epidermal nerves (Gibran et al., 2002 ), bone healing, and balance between the accumulation of ECM components and their remodeling by MMPs (Lobamann et al., 2002). The phytochemical analysis of the ethanolic extracts of $C$. infortunatum plants indicated the presence of major phytochemical compounds, including alkaloids, glycosides, reducing sugars, sterol, terpene were found in higher extent which may have been responsible for the observed wound healing activities, anti-inflammatory activity, antioxidant activities and antimicrobial activities (Abbaszadeh et al.,2014; Kapoor et al.,2001). C. infortunatum ethanolic extract contained phenolics constitute one of the major groups of compounds that act as primary antioxidants or free radical scavengers. Flavonoids are probably the most important natural phenolics that possess a broad spectrum of chemical and biological activities including free radical scavenging properties (Pal et al., 2009). The pattern of wound healing is clearly visible through photographs taken on different days and evidenced by $\%$ wound contraction. The significant increment in wound contraction was seen in the C.infortunatum-treated group. This might be attributed to the anti-apoptotic, anti-inflammatory, and anti-oxidative property, which results in conditions conducive for proliferation, transformation of fibroblasts into myofibroblasts, and reepithelialisation (Dunphy et al., 1956; Brouard et al., 2000; Zhang et al., 2003). These results are in agreement with Davis et al., (1997) reported that the ethanolic extract of $C$. infortunatum leaves having the property of anti-inflammatory activity along with it is a good approach for treating wounds, oedema, and pain in diabetes. Furthermore, the period of re-epithelialisation was shorter in C.infortunatum treated wounds as compared with control confirmed by $\mathrm{H} \& \mathrm{E}$ staining of granulation tissue on day 15 . The anti-oxidant properties of $C$. infortunatum was also further supported by the result obtained in this study of anti-oxidant enzymes (SOD, CAT, GSH) and MDA levels for lipid peroxidation.

Enzymatic antioxidant mechanisms play an important role in scavenging free radicals (ROS). SOD catalyses the dismutation of $\mathrm{O}_{2}^{-}$ into oxygen and $\mathrm{H}_{2} \mathrm{O}_{2}$, thus decreases ROS generation and oxidative stress (Segue et al., 2004; Ponrasu et al., 2013). Increased activity of SOD has been reported to scavenge the superoxide radicals to protect the tissue damage by free radicals (Shirwaikar et al., 2003; Gupta et al., 2012). It can be suggested that accumulation of excessive $\mathrm{H}_{2} \mathrm{O}_{2}$ in wound tissues due to increased activity of SOD might be properly neutralised by increased CAT activity ( Barua et al., 2012; Ponrasu et al., 2013). Catalase was one of the most efficient enzymes and cannot be saturated by $\mathrm{H}_{2} \mathrm{O}_{2}$ at any concentration 
(Liedias et al., 1998). In the present study, SOD and CAT activity was significantly increased in the C.infortunatum treated diabetic group as compared to control group. There was also significant increased in the level of reduced glutathione (GSH), it acts as an effective antioxidant protecting the cellular component from oxidative damage caused by ROS (Pompella et al., 2003, Venukumar and Latha 2002).)

MDA production is an index of lipid peroxidation (Kakkar et al., 1998). The production of free radicals increases the peroxidation of lipid molecules. In the present study, $C$. infortunatum diabetic treated rats, the lipid peroxidation was significantly lower as compared to control rats, which indicates that $C$. infortunatum was able to prevent lipid peroxidation by scavenging free radicals. These results were in agreement with $\mathrm{Pal}$ et al., (2009) reported that methanolic extract of C. infortunatum showed significant increase amount of percentage inhibition in oxidation with increase in its concentration.

The ethanolic extract of $C$. infortunatum increased cell proliferation and collagen synthesis at the wound site as evidenced by total collagen content reflected by hydroxyproline content of granulation tissue (Woessner, 1961). These results were in agreement with Udupa et al., (1995); Kirtikar et al., (2001) reported that the ethanolic extract of $C$. infortunatum ointment increases the tensile strength of the excision wound by significantly increasing the hydroxyproline content of the granulation tissue in both treated groups.

The efficacy of $C$. infortunatum in wound healing is also supported by fast and early reepithelialization visualized on $\mathrm{H} \&$ E-stained wound sections. The representative images of H\&E-stained sections are presented in Figure 8. On day 3, C. infortunatum diabetic treated tissue sections showed more fibroblast with some collagen deposition and few inflammatory cells in comparison to control group. On day 7, diabetic treated group exhibited uniform and thick granulation tissue formation with marked proliferation of fibroblasts, well-formed new blood vessels and few inflammatory cells. However, wound area of control group was dominated by more cells that are inflammatory and loosely formed less granulation tissue. On day 15, the thick granulation tissue was dominated by fibroblasts and increased collagen fibers deposition and the complete newly regenerated epithelial layer in diabetic treated rats covered it. However, control groups still showed the dominant presence of inflammatory cells and thin granulation tissue. The $C$. infortunatum ointment treated group showed thick compact extracellular matrix (ECM) covered by epithelial layer resembling normal skin. The fibroblasts proportion also decreased in the treated wounds on day 15, as compared to day 15 of diabetic control group where as diabetic control rats were still dominated by inflammatory cells with some fibroblasts and collagen deposition. The same trends of results were also reported by Sidarth et al., 2016; Prasad et al., (2017) in excision wound model in normal rats, Albuquerque et al., (2009) in bovine type-1 collagen application in rodents. The early re-epithelialisation and faster wound closure in treated wound might also be associated with increased levels of anti-oxidants enzymes, attenuation of LPO, keratinocyte proliferation and migration to wound site, anti-microbial activity and more hydroxyproline synthesis.

In conclusion, the treatment of cutaneous excision wounds with $C$. infortunatum ointment (4\%) showed a potent pro-healing activity which may be attributed by reducing lipid peroxidation and by increasing the synthesis of anti-oxidant enzymes. It has also 
shown anti-inflammatory activity, better collagen deposition, early re-epithelialization and better angiogenesis.

\section{Acknowledgment}

The authors are thankful to the Hon'ble ViceChancellor, BAU and Dean, RVC for providing fund and necessary facilities to conduct the experiment

\section{Conflict of interest}

The authors declare that there are no conflicts of interest.

\section{References}

Abbaszadeh, G., Srivastava, C. and Walia, S. 2014. Insecticidal and antifeedant activities of Clerodone diterpenoids isolated from the Indian bhant tree, Clerodendron infortunatum, against the cotton bollwarm, Helicoverpa armigera. J. Insect Sci.14 (29):1-13.

Albuquerque-Jr., Barreto, R.L.C., Pires, A.J., Reis, P.F., Lima, O.S., Ribeiro, G.M.A. and Cardoso, C. J. 2009. Effect of bovine type-1 collagenbased films containing red propolis on dermal wound healing in rodent model. Int. L. Morph. 27 (4):11051110.

Barau, C.C., Talkdar, A., Begum, S.A., Boragohain, B., Roy, J.D., Pathak, D.C., Sharma,D.K., Gupta,A.K., and Bora, R.S. 2012. Effect of Alternanthera brasiliana (L) Kuntze on healing of dermal burn wound. Indian J Exp Biol. 50:56-60.

Bergmeyer,H.U.1983. U.V. method of catalase assay. In methods of enzymatic analysis vol. $1113^{\text {rd }}$ ed. Weinheim, Decrfield beah, Florida, Basal.pp. 273.

Brouard, S., Otterbein, L.E. and Anrather, J.
2000. Carbon monoxide generated by heme oxygenase 1 suppresses endothelial cell apoptosis. J. Exp. Med. 192:1015-1026.

Davis, R.H., Leitmer, M.G. and Russo, J.M. 1994. Aloe vera, a natural approach for treating wounds, oedema, pain in diabetes. J. Am. Podiatric Med. Assoc. 78(2):60-68.

Davis,R.H.1997.Clerodendrum infortunatum: A Scintific approach by Roberts, $\mathrm{H}$. Davis, PhD, published by Vantage Press (New York,NY10001,USA).

Diegelmann, R.F. and Evans, M.C. 2004. Wound healing: an overview of acute, fibrotic and delayed healing. Front. Bio. Sci. 9:283-289.

Dunphy, J.E. and Udupa, K.N. 1956. Chemical and histochemical sequences in the normal healing of wounds. N. Eng. J. Med. 253: 847852

Dymock, W. 1976. Pharmacographia indica.Vol.3,M/S periodical experts ,Vivek Vihar, Delhi,PP.79-80.

Falanga, V. 2005. Wound healing and its impairment in the diabetic foot. Lancet. 366:1736-1743.

Galiano, R.D., Tepper, O.M., Pelo, C.R., Bhatt, K.A., Callaghan, M. and Bastidas, N. (2004). Topical vascular endothelial growth factor accelerates diabetic wound healing through increased angiogenesis and by mobilizing and recruiting bone marrow-derived cells. Am. J. Pathol. 164: 1935-1947.

Galkowska, H., Wojewodzka, U. and Olszewski, W.L. 2006. Chemokines, cytokines, and growth factors in keratinocytes and dermal endothelial cells in the margin of chronic diabetic foot ulcers. Wound Repair. Regen.14: 558-565.

Gibran, N.S., Jang, Y.C., Isik, F.F., Greenhalgh, D.G., Muffley, L.A., 
Underwood, R.A., Usui, M.L., Larsen, J., Smith, D.G., Bunnett, N., Ansel, J.C., and Olerud, J.E. 2002. Diminished neuropeptide levels contribute to the impaired cutaneous healing response associated with diabetes mellitus. J. Surg. Res., 108: 122-128.

Goren, I., Muller, E., Pfeilschifter, J. and Frank, S. 2006. Severely impaired insulin signaling in chronic wounds of diabetic ob/ob mice: a potential role of tumor necrosis factor-alpha. Am. $J$. Pathol., 168: 765-777.

Gupta, R. and Singh, H.K. 2012. Nootropic potential of Alternanthera sessilis and Clerodendrum infortunatum leaves on mice. Asian Pac J Trop Dis. S4 65-70.

Jain, S.K. 1988. Evidence for membrane lipid peroxidation during in vivo again of human erythrocytes. Biochem. Biophysica. Acts .937:205-210.

Kakkar, R., Mantha, S.V., Radhi, J., Prasad, K. and Kalra J.1998. Increased oxidative stress in rat liver and pancreas during progression of streptozotocin -induced diabetes. Clinical sci. 94:623-632.

Kapoor LD. (2001). Handbook of Ayurvedic Medicinal Plants. 1st ed. New Delhi: CRC Press; 12:4-5.

Kirtikar, K. R. and Basu, B. D. 2001. Indian Medicinal Plants Vol. II, edited by K S Mhaskar and J F Cains (Sri Satguru Publications, Delhi). 1424-1426

Lledias, F. and Rangelphansberg, W. 1998. Oxidation of Catalase by singlet oxygen. J. Bio. Chem. 273 (17):10630-10637.

Lobmann, R., Zemlin, C., Motzkau, M., Reschke, K. and Lehnert, H. (2002). Expression of matrix metalloproteinases and growth factors in diabetic foot wounds treated with a protease absorbent dressing. J. Diabetes Complicat. 20:
329-335.

Madesh, M., and Balasubramanium, K.A.1998 . Microtitre plate assay for superoxide dismutase using M.T.T. reduction by superoxide. Indian. $J$. Biochem. Biophysics. 35: 184-188.

Maisch, J.M. 1885. Some useful plants of the natural odour of Verbanaceae Am.J.pharma.52:142-145.

Martin, A., Komada, M.R. and Sane, D.C. 1991. Abnormal angiogenesis in diabetes mellitus. Med Res Rev .23:117-145

Maruyama, K., Asai, J., Ii, M., Thorne, T., Losordo D. W. and Amore, P.A. 2007. Decreased macrophage number and activation lead to reduced lymphatic vessel formation and contribute to impaired diabetic wound healing. Am. J. Pathol., 170: 1178-1191.

Mehmood, I., Mohammed, M., and Ahmad, Z.F. 2011. Anti-oxidant effect of Clerodendrum infortunatum LINN. Journal of Ethnopharmacology. 62:183-93.

Pal, D., Sannigrahi, S. and Mazumder, U.K. 2009. Analgesic and anticonvulsant effects of saponin isolated from the leaves of Clerodendrum infortunatum Linn. in mice. Indian. J. Exp. Biol.47:743-747.

Pandrinathan, C., Sajithlal, G.B., Chandrakasan, G., Chitra, P. and Chandrakasan, G. 1998. Influence of Clerodendrum on collagen characteristics in healing dermal wounds in rats. Molecular and cellular-biochemistry. 181; 1-2, 71-76.

Pompella, A., Visvikis, A., Paolichi, A., Tata, D. and Casini, A.F. 2003. The changing faces of glutathione, a cellular potagonist. Biochem. Pharmacol. 66: 1499-1503.

Ponrasu, T., Kannapan, M.S., Kumar, G. M. and Suguna, L. 2013. Role Of Annona squamosa on antioxidants during 
wound healing in streptozotocin nicotinamide induced diabetes rats. $J$. Pharmacog. Phytochem. 2(4): 77-84.

Prasad R, Kumar D, Kant V, Tandan S. K. and Kumar D. 2017. Curcumin Enhanced Cutaneous Wound Healing by Modulating Cytokines and Transforming Growth Factor in Excision Wound Model in rats Int. J. Curr. Microbiol. App. Sci. 6(7): 2263 2273

Prins, H. K and Loos, J. A. 1969. Biochemical methods in red cell genetics. Academic Press, New York. pp. 127-129.

Segue, J., Gironella, M., Sans, M., Granel, S., Gil, F., Gimeno, M., Coronel, P., Pique, J.M., and Panes, J. 2004. Superoxide Dismutase ameliorates TNBS- induced colites by reducing oxidative stress, adhesion molecule expression and leukocyte recruitment into inflamed intestine. J. Leukoc. Boil. 76: 537-544.

Shafiuddin M., Khan A. and Ali S., 2009. Wound healing activity of traditional herbal formulation Int. J. Chem. Sci.: 7(2): 639-643.

Shirwaikar, A., Somashekhar A.P., Udupa, A. L., Udupa, S.L. and Somashekhar, S. 2003. Wound healing studies of the Aristolochia bracteolate lam with supportive action of antioxidant enzymes . Phytomedicine.10: 558-562.

Sidharth S Panigrahi, Raju Prasad, Mahendra Ram, BK Roy, AK Sharma, KK Singh 2016. Clerodendrum infortunatum linn accelerates wound healing in cutaneous exicisional wound model in rats. Journal of Veterinary Pharmacology And Toxicology., 15(1) 62-67

Stock, J. And Dormandy, T.L. 1971. The auto oxidation of human red cell lipid induced by hydrogen peroxidation . Br. J. Haematol. 20:95-111.

Tyler, V.E. and Robbers, J.E. 1999. The therapeutic use of phytomedicinals. In Tyler's Herbs of choice. Haworth press, Inc. Pharmaceutical Production Press. N.Y. Vol. 1(2).

Udupa, S.L. ,Udupa , A.L. and Kulkarni, D.R. 1994 . Studies on the anti inflammatory and wound healing process of Moringa oleifera and Agele marmelos. Fitoterapia ,65(2) :119123.

Venukumar M.R. and Latha M.S. 2002. antioxidant activity of curculigo orchioides in carbon tetrachloride induced hepatopathy in rats. Indian. $J$. Clin. Biochem.17:80-87.

Woessner, J.F. Jr., 1961. The determination of hydroxyproline in tissue and protein sample containing small proportions of this amino acid. Arch. Biochem. Biophys. 93: 440-447.

Zhang, X., Shan, P., Alam, J., Davis, R.J., Flavell, R.A., and Lee, P.J. 2003. Carbon monoxide modulates Fas/Fas ligand, caspases and Bcl-2 family proteins via the p38á mitogenactivated protein kinase pathway during ischemia-reperfusion lung injury. Journal of Biological Chemistry., 24.

\section{How to cite this article:}

Sidarth S. Panigrahi, Raju Prasad, Mahendra Ram, Dipshikha, A.K. Sharma, B.K. Roy and Singh, K.K. 2018. Efficacy of Clerodendrum infortunatum on Wound Healing in Streptozotocin-Induced Diabetic Rats. Int.J.Curr.Microbiol.App.Sci. 7(02): 1979-1991. doi: https://doi.org/10.20546/ijcmas.2018.702.237 